\title{
Cost management of a construction company based on functional cost analysis
}

\author{
Olga Borovskikh ${ }^{10000-0002-2964-2301]}$, Alsu Evstafieva $^{1}{ }^{{ }^{[0000-0002-2994-2830]}}$, and Ludmila Marfina ${ }^{1}$ \\ ${ }^{1}$ Kazan State University of Architecture and Engineering, 420043, Zelenay ast., Kazan, Russia
}

\begin{abstract}
In conditions of environmental instability and uncertainty, one of the factors for the effective functioning and development of a construction company is high-quality and continuous cost management. The cost management process is aimed at maximizing profits by increasing the efficiency of the use of all resources. It requires constant monitoring to make adjustments to the planned costs and their amounts. Cost management is impossible without careful analysis. Along with the traditional methods of cost management, it is advisable for construction companies to apply functional cost analysis, which is an effective tool for optimizing costs and the quality of production functions performance. The research studies a construction company. Particular attention in the study is paid to indirect costs due to an increase in their share in the structure of the construction products cost. Within the framework of the functional cost analysis, an $\mathrm{ABC}$ analysis was carried out and a Pareto curve was modelled. It allowed us to focus on the allocated cost areas and classify the processes into main, basic and supportive ones. The significance of the identified processes was determined using the paired comparisons method. The results obtained allow us to draw a conclusion about the correspondence of the share of cost items and their significance for the analyzed construction company. The research materials are of interest and practical importance for the CEOs of construction companies.
\end{abstract}

Keywords: cost management, functional cost analysis, $\mathrm{ABC}$ analysis, construction company, process.

\section{Introduction}

Cost management issues occupy an important place in the activities of any company. The main research trends in this area are determined by the works of scientists in various sectors of the economy.

Braga, G.H.R., Cervi, R.G., de Oliveira, P.A., Rodrigues, S.A. point out that companies need to increase control over production processes and costs. They see the solution to these problems due to the most efficient distribution of indirect costs[1].

Sinha, V. K., Chandra, B., Pattanayak, J. K.; Suskova, A. Buchtova, J. presented different points of view on choosing the optimal cost allocation. They also highlighted the

\footnotetext{
*Corresponding author: evalsu@yandex.ru
} 
advantages in the field of cost integration in the company using a calculation system based on the $\mathrm{ABC}$ analysis method[2], [3].

Demina, I., Bergal, E., Bezrukov, D. developed a model for the distribution of indirect costs by function[4]. Vetchagool, W., Augustyn, M. M., Tayles, M. hypothesize and statistically test various models of possible positive impact of activity-based cost calculation[5].

The issue of cost management and overhead costs allocation using the method of cost calculation by activity is studied in the research of the following scientists: Janovska, K., Vilamova, S., Piecha, M., Kutac, J., Kozel, R., Citbajova, J.[6].

Cost issues in the construction industry are considered by such researchers as: $\mathrm{Vu}, \mathrm{T}$. Q., Pham, C. P., Nguyen, T. A., Nguyen, P. T., Phan, P. T., LeHoang Thuy To Nguyen, Q. [7]; Tomczak, M., Jaśkowski, P. [8]; Kharisov, I. , Artamonova, I., Bilenko, P., Sborshikov, S. [9]; Saidova, M. Kh., Xodjimuxamedova, Sh.I., Dadarbaev, M. A.[10]; Nalimova, A. V.[11]; Chepachenko, N. V., Leontiev, A. A., Uraev, G. A., Polovnikova, N. A.[12]; Hyari, K. H, Al-Daraiseh, A, El-Mashaleh, M. [13]; Garcia de Soto B., AgustíJuan I., Hunhevicz J., Joss S., Graser K., Habert G., Adey B.[14], Habibi, M., Kermanshachi, S., Safapour, E. [15].

Construction enterprises, in the struggle for new customers, strive to form a competitive price, which is based not only on forecasting resource provision for the construction of a property, but also on the methods for optimizing the use of resources in physical and monetary terms.

The goal of the study is aimed at ensuring the transparency in all costs accounting and improving their management. Achieving this goal is possible through the use of modern cost management methods: functional-cost and $\mathrm{ABC}$ analysis.

The use of these methods will allow the management team of the construction company to calculate the cost of construction products more accurately and, on its basis, establish the optimal price; provide the necessary data for the development of the companybudget; evaluate the cost of processes or activities of company departments, as well as other decisions of both operational and prospective nature [16].

Among the world famous companies, the methodology of functional cost analysis and its modifications are used by such companies as: Boeing, DuPontCo., Fiat, Ford, General Electric, General Motors Corp., Hewlett-Packard, Mitsubishi, Motorola, Royal Dutch/Shell Group, Toyota, Volkswagen, Nissan Motor, Northern Telecom, Xerox Corp [17].

\section{Methods}

In this study, the authors used the methods of functional cost analysis and $\mathrm{ABC}$ analysis. They cannot be regarded as one and the same method of analysis.

Comparing these two methods we should point out that their main goals differ. The main goal of the $\mathrm{ABC}$ method is to achieve the accuracy of product costing and cost management, and also to obtain updated information for pricing needs. And the main goal of the functional cost analysis is not only to determine the cost of a function, but also to identify the most economical solution option.

The ABC analysis is based on the Pareto principle [18].Using the ABC method,it is possible to calculate direct and indirect costs more accurately, and match them with the corresponding cost objectives. ABC analysis is one of the stages of functional cost analysis. When conducting the functional cost analysis, the prioritization method and the method of paired comparisons were used [19]. 


\section{Results and discussion}

The issues of choosing and developing an optimal cost system and improving the accounting methodology are reaching the level of priority problems associated with the effective management of a construction company.

The quality of the functional and cost analysis by a construction company is determined by its information and organizational support. The result of the analysis depends on the organization and level of all analytical work of the company.

Numerous studies conducted by the authors show that the functional cost analysis is used by construction companies to solve the following problems: improving the consumer properties of construction products at constant or lower costs; reducing the cost of manufacturing construction products while maintaining the established consumer properties[20].

The starting point of the functional cost analysis is the idea that not the product itself is valuable for the consumer but a certain set of its useful functions. For example, the buyer is not interested in the property itself as it is, but in the comfort of living in this residential property. Thus, the functional approach means that the object is understood and improved not in its specific tangible or other form, but as a set of processes (functions) that are performed (or should be performed).

Conducting a functional cost analysis should be continuous at all stages of the studied property life cycle (design stage, construction stage). For the analysis, it is necessary to study the organizational structure, provide main, service and control processes, collect and organize data in each process; determine the total amount of costs, the share of costs in the total amount for the implementation of each process.

Many authors have considered the stages and sequence of the functional cost analysis[21], [22], [23], [24], [25].

The authors carried out functional cost analysis using a construction company as an example. The organizational structure of the company was investigatedand, on its basis, we distinguished the processes, which are subdivided into supporting and controlling ones. For each process, data was collected and systematized on the total amount of costs, the share of costs in the total amount for the implementation of each process per month. Depending on the share of each process, they were ranked (Table 1).

Then the ABC analysis was carried out and the Pareto curve was constructed (Fig. 1).

The essence of the analysis is to group the processes under study into three zones in order to work separately with each of them. This analysis helps to highlight key points and gives the ability to concentrate on analysing three areas, instead of a large list of processes. The positions within a zone can be handled according to the same principles. The ABC analysis method is based on the Pareto principle, according to which «20\% of efforts give $80 \%$ of the result». Classic ABC analysis consists of $80 / 15 / 5$ proportions. Zone A: minimum value $-80 \%$; zone B: $80 \%-95 \%$; zone C: $95 \%-100 \%$.

$\mathrm{ABC}$ analysis revealed 8 processes that fell into zone $\mathrm{A}$, which account for $77 \%$ of all costs (Fig. 1), namely:

- repair of construction machinery and equipment $-13.5 \%$;

- purchase of materials $-12.5 \%$;

- supervision of every stage of construction $-10.5 \%$;

- maintenance of machinery and equipment $-9.4 \%$;

- estimate and contractual support $-8.6 \%$;

- recruitment $-8.3 \%$;

- legal support $-7.2 \%$;

- accounting and management accounting $-6.9 \%$. 
Any change in the technological process, the range of services provided, the financial or administrative structure of the construction company and the amount of costs should be reflected in the ABC analysis model. The model is developed once, but in the future, it must be adjusted with any change in the technological process.

Table1. Items of functional cost analysis.

\begin{tabular}{|l|c|c|c|}
\hline \multicolumn{1}{|c|}{ Name } & $\begin{array}{c}\text { Cost } \\
\text { amount per } \\
\text { month, } \\
\text { rub. }\end{array}$ & $\begin{array}{c}\text { Share of costs } \\
\text { in total } \\
\text { amount, \% }\end{array}$ & Rating \\
\hline Supporting processes & 567342 & $12.5 \%$ & 2 \\
\hline - purchase of materials & 36892 & $0.8 \%$ & 16 \\
\hline - storage of materials & 377122 & $8.3 \%$ & 6 \\
\hline - recruitment & 150867 & $3.3 \%$ & 11 \\
\hline - work organization and staff motivation & 425333 & $9.4 \%$ & 4 \\
\hline - maintenance of machinery and equipment & 613444 & $13.5 \%$ & 1 \\
\hline - repair of construction machinery and equipment & 156221 & $3.4 \%$ & 10 \\
\hline - IT - technical support and internet connection & 325432 & $7.2 \%$ & 7 \\
\hline - legal support & 65789 & $1.5 \%$ & 15 \\
\hline - occupational Safety and Health & 389432 & $8.6 \%$ & 5 \\
\hline - estimate and contractual support & 312887 & $6.9 \%$ & 8 \\
\hline - accounting and management accounting & 125443 & $2.8 \%$ & 12 \\
\hline - document flow & 101992 & $2.2 \%$ & 14 \\
\hline - operation of buildings, premises, territory & 120443 & $2.7 \%$ & 13 \\
\hline - works quality control & 478547 & $10.5 \%$ & 3 \\
\hline Controlling Processes & 289655 & $6.4 \%$ & 9 \\
\hline - supervision of every stage of construction & 4536841 & $100 \%$ & - \\
\hline - putting the property into operation & & & \\
\hline Total & & & \\
\hline
\end{tabular}

Source: calculated by the authors 


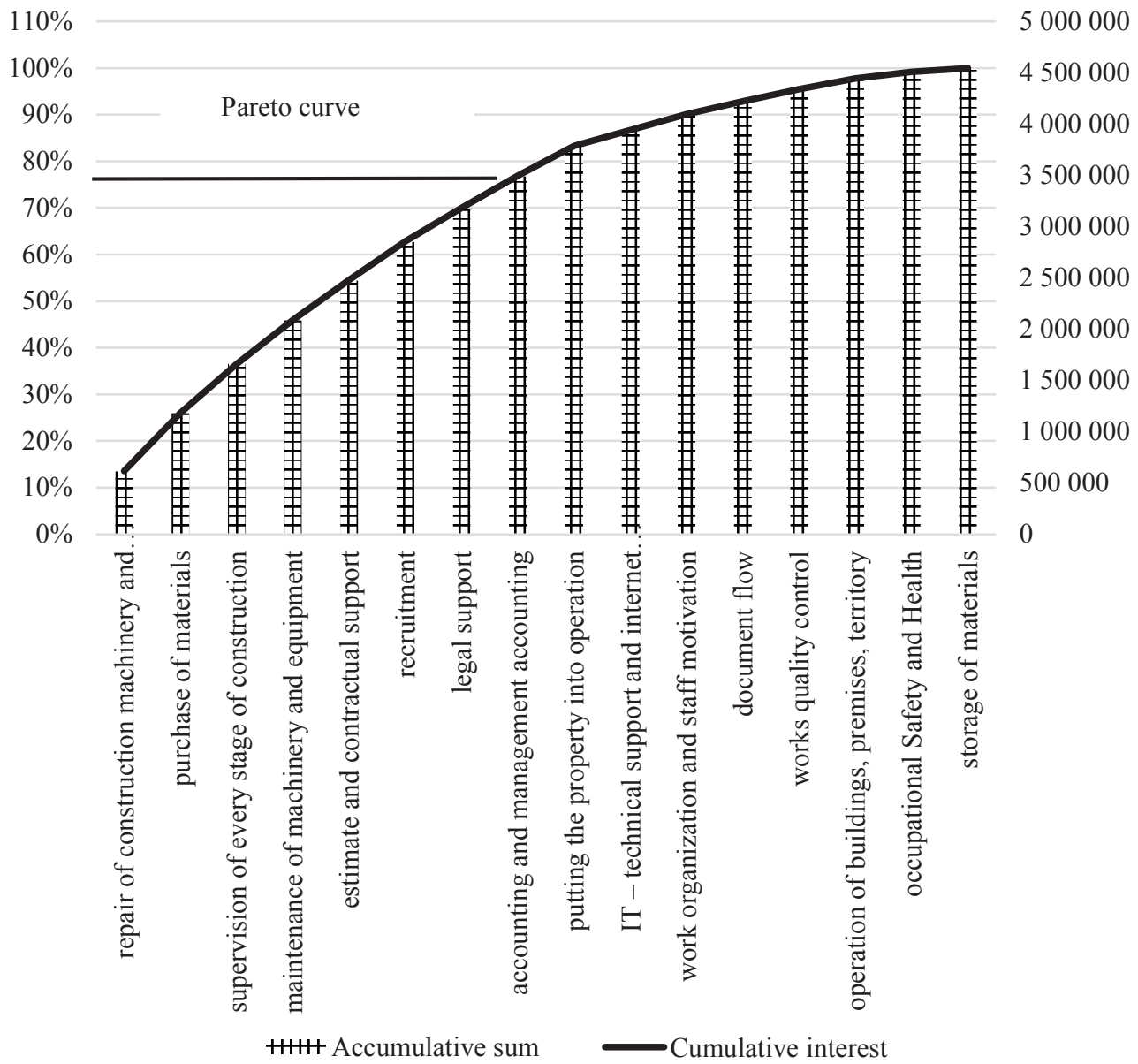

Fig. 1. Identification of priority research issues for functional and cost analysis using the $A B C$ model (ABC analysis). Source: calculated by the authors.

Further, the processes were classified according to their importance:

- the main processes - these processes are aimed at achieving the goal of the system, at the direct satisfaction of specific final needs;

- basic processes are the processes without which the system cannot provide the required consumer properties, the existence of the main process;

- supportive processes are the processes that contribute to the implementation of the main processes or supplement them.

The processes formulation and their classification are presented in the Table 2.

Each process has its own code, which reflects the belonging to a certain level of the functional model, and it is necessary to determine the significance of each process in relation to the main process «construction of a real estate property».

The significance of the processes in this study is determined using the prioritization method. In prioritization, the method of paired comparisons is adopted as a method for expressing expert judgments.

The main idea of the method of paired comparisons is to establish the significance of each process of the lower level in relation to the higher one. Based on this, we identify priority relationships by successive pairwise comparison of them with each other. 
The CEOs of construction companies who directly create the development strategy and are also responsible for determining the priorities of the processes can act as experts assessing the significance of the processes.

Table 2. Items of functional cost analysis.

\begin{tabular}{|l|c|c|}
\hline \multicolumn{1}{|c|}{ Name } & Process type & Code \\
\hline Construction of a real estate property & & \\
\hline Supply of building materials & Main & F0 \\
\hline - purchase of materials & Supportive & F1.1 \\
\hline - storage of materials & Supportive & F1.2 \\
\hline Providing qualified personnel & Basic & F2 \\
\hline - recruitment & Supportive & F2.1 \\
\hline - work organization and staff motivation & Supportive & F2.2 \\
\hline Machines and mechanisms support & Bacic & F3 \\
\hline - maintenance of machinery and equipment & Supportive & F3.1 \\
\hline - repair of construction machinery and equipment & Supportive & F3.2 \\
\hline Administrative support & Basic & F4 \\
\hline - IT - technical support and internet connection & Supportive & F4.1 \\
\hline - legal support & Supportive & F4.2 \\
\hline - occupational Safety and Health & Supportive & F4.3 \\
\hline - estimate and contractual support & Supportive & F4.4 \\
\hline - accounting and management accounting & Supportive & F4.5 \\
\hline - document flow & Supportive & F4.6 \\
\hline - operation of buildings, premises, territory & Supportive & F4.7 \\
\hline Construction process management & Basic & F5 \\
\hline - supervision of every stage of construction & Supportive & F5.2 \\
\hline - works quality control & Supportive & F5.3 \\
\hline - putting the property into operation & & F5.1 \\
\hline
\end{tabular}

Source: calculated by the authors

To rank the processes under study by the prioritization method, we designated them in the following way:

$$
F_{1}, F_{1.1} \ldots F_{m n}
$$

$\mathrm{m}$-number of functional model levels;

$n$ - number of investigated processes. Then we develop the matrix:

$$
A=\left\|a_{i j}\right\|
$$

$a_{i j}$ - matrix A element, consisting of the processes $F_{1}, F_{1.1} \ldots F_{n m}$; 


$$
a_{i j}=\left\{\begin{array}{c}
1.5 ; \text { if } F_{i}>F_{j} \\
1 ; \text { if } F_{i}=F_{j} \\
0.5 ; \text { if } F_{i}<F_{j}
\end{array}\right\}
$$

where $F_{i}>F_{j}$ - means, that the $\mathrm{i}$-th process is more preferable than the $\mathrm{j}$-th process;

$F_{i}=F_{j}$ - means that the $\mathrm{i}$-th and $\mathrm{j}$-th processes are equivalent;

$F_{i}<F_{j}$ - means that the $\mathrm{i}$-th process is less preferable than the $\mathrm{j}$-th process.

At the next stage, an adjacency matrix is built for each selected basic process (Table 3, $4,5,6,7)$.

Table 3. Adjacency matrix for the basic process «Supply of building materials - F1».

\begin{tabular}{|c|c|c|c|c|c|}
\hline \multirow{2}{*}{ Code } & \multicolumn{2}{|c|}{ Process code } & \multirow{2}{*}{$\begin{array}{c}\text { Sum of } \\
\text { values } \\
\text { horizontally }\end{array}$} & \multirow{2}{*}{$\begin{array}{l}\text { Absolute } \\
\text { priorities }\end{array}$} & \multirow{2}{*}{$\begin{array}{l}\text { Relative } \\
\text { priorities }\end{array}$} \\
\hline & F1.1 & F1.2 & & & \\
\hline F1.1 & 1 & 1.5 & 2.5 & 4.75 & 0.63 \\
\hline F1.2 & 0.5 & 1 & 1.5 & 2.75 & 0.37 \\
\hline Total & 1.5 & 2.5 & 4 & 7.5 & 1 \\
\hline
\end{tabular}

Source: calculated by the authors.

Table 4. Adjacency matrix for the basic process «Providing qualified personnel - F2».

\begin{tabular}{|c|c|c|c|c|c|}
\hline \multirow{2}{*}{ Code } & \multicolumn{2}{|c|}{ Process code } & \multirow{2}{*}{$\begin{array}{c}\text { Sum of } \\
\text { values } \\
\text { horizontally }\end{array}$} & \multirow{2}{*}{$\begin{array}{l}\text { Absolute } \\
\text { priorities }\end{array}$} & \multirow{2}{*}{$\begin{array}{l}\text { Relative } \\
\text { priorities }\end{array}$} \\
\hline & F2.1 & F 2.2 & & & \\
\hline $\mathrm{F} 2.1$ & 1 & 1.5 & 2.5 & 4.75 & 0.63 \\
\hline F2.2 & 0.5 & 1 & 1.5 & 2.75 & 0.37 \\
\hline Итого & 1.5 & 2.5 & 4 & 7.5 & 1 \\
\hline
\end{tabular}

Source: calculated by the authors.

Table 5. Adjacency matrix for the basic process «Providing machines and mechanisms - F3».

\begin{tabular}{|c|c|c|c|c|c|}
\hline \multirow{2}{*}{ Code } & \multicolumn{2}{|c|}{ Process code } & \multirow{2}{*}{$\begin{array}{c}\text { Sumof } \\
\text { values } \\
\text { horizontally }\end{array}$} & \multirow{2}{*}{$\begin{array}{c}\text { Absoluteprior } \\
\text { ities }\end{array}$} & \multirow{2}{*}{$\begin{array}{c}\text { Relativeprioritie } \\
\text { S }\end{array}$} \\
\hline & F3.1 & F3.2 & & & \\
\hline F3.1 & 1 & 0.5 & 1.5 & 2.75 & 0.37 \\
\hline F3.2 & 1.5 & 1 & 2.5 & 4.75 & 0.63 \\
\hline Итого & 2.5 & 1.5 & 4 & 7 & 1 \\
\hline
\end{tabular}

Source: calculated by the authors. 
Table 6. Adjacency matrix for the basic process «Administrative support - F4».

\begin{tabular}{|c|c|c|c|c|c|c|c|c|c|c|}
\hline \multirow{2}{*}{ Code } & \multicolumn{7}{|c|}{ Process code } & \multirow{2}{*}{ 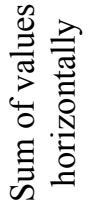 } & \multirow{2}{*}{ 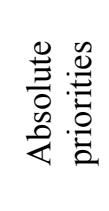 } & \multirow{2}{*}{ 总 } \\
\hline & F4.1 & F4.2 & F4.3 & F4.4 & F4.5 & F4.6 & F4.7 & & & \\
\hline F4.1 & 1 & 0.5 & 1 & 0.5 & 0.5 & 1.5 & 1.5 & 6.5 & 42.5 & 0.1 \\
\hline F4.2 & 1.5 & 1 & 1 & 1.5 & 1.5 & 0.5 & 0.5 & 7.5 & 55.0 & 0.2 \\
\hline F4.3 & 1 & 1 & 1 & 0.5 & 0.5 & 1.5 & 1 & 6.5 & 43.3 & 0.1 \\
\hline F4.4 & 1.5 & 0.5 & 1.5 & 1 & 1 & 1.5 & 1.5 & 8.5 & 58.5 & 0.2 \\
\hline F4.5 & 1.5 & 0.5 & 1.5 & 1 & 1 & 1.5 & 1.5 & 8.5 & 57.5 & 0.2 \\
\hline F4.6 & 0.5 & 1.5 & 0.5 & 0.5 & 0.5 & 1 & 1 & 5.5 & 37.8 & 0.1 \\
\hline F4.7 & 0.5 & 1.5 & 1 & 0.5 & 0.5 & 1 & 1 & 6 & 41.0 & 0.1 \\
\hline Total & 7.5 & 6.5 & 7.5 & 5.5 & 5.5 & 8.5 & 8 & 49 & 335.5 & 1.0 \\
\hline
\end{tabular}

Source: calculated by the authors.

Table 7. Adjacency matrix for the basic process «Construction process management - F5».

\begin{tabular}{|c|c|c|c|c|c|c|}
\hline \multirow{2}{*}{ Code } & \multicolumn{3}{|c|}{ Process code } & \multirow{2}{*}{$\begin{array}{c}\text { Sum of } \\
\text { values } \\
\text { horizontally }\end{array}$} & \multirow{2}{*}{$\begin{array}{l}\text { Absolute } \\
\text { priorities }\end{array}$} & \multirow{2}{*}{$\begin{array}{l}\text { Relative } \\
\text { priorities }\end{array}$} \\
\hline & F5.1 & F5.2 & F5.3 & & & \\
\hline F5.1 & 1 & 1.5 & 1.5 & 4 & 13 & 0.4 \\
\hline F5.2 & 0.5 & 1 & 1.5 & 3 & 9.5 & 0.3 \\
\hline F5.3 & 0.5 & 1.5 & 1 & 3 & 9.5 & 0.3 \\
\hline Total & 2 & 4 & 4 & 10 & 32 & 1 \\
\hline
\end{tabular}

Source: calculated by the authors.

Due to the fact that five basic processes were identified for carrying out a functional cost analysis $\mathrm{Fi}$, each of them can be assigned the same significance, equal to $20 \%$. For supportive processes, significance was also determined based on the calculated relative priorities in the adjacency matrices and attribution to the basic process.

After determining the significance and costs of each process, it is possible to proceed to a reasonable cost diagnosis of the process system and find out the degree of correspondence between costs and their significance. For this purpose, a functional cost diagram is developed, which is a combined diagram of processes significance and cost structure.

Table 8 shows the costs for the implementation of the main process, each of the basic and supportive processes; it also shows the share of costs in the total amount of costs (\%) and their significance $(\%)$. 
Table 8. Significance and costs of processes.

\begin{tabular}{|c|c|c|c|c|c|}
\hline Name & Type of the process & Code & 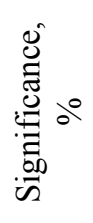 & $\begin{array}{l}\dot{0} \\
\dot{E} \\
\dot{0} \\
\dot{0}\end{array}$ & 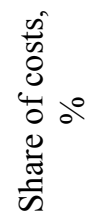 \\
\hline $\begin{array}{l}\text { Construction of real estate } \\
\text { property }\end{array}$ & Main & F0 & 100 & 4536841 & 100 \\
\hline $\begin{array}{l}\text { Supply of building } \\
\text { materials }\end{array}$ & Basic & $\mathrm{F} 1$ & 20 & 604234 & 13.3 \\
\hline - purchase of materials & Supportive & F1.1 & 12.6 & 567342 & 12.5 \\
\hline - storage of materials & Supportive & F1.2 & 7.4 & 36892 & 0.8 \\
\hline $\begin{array}{l}\text { Providing qualified } \\
\text { personnel }\end{array}$ & Basic & F2 & 20 & 527989 & 11.6 \\
\hline - recruitment & Supportive & F2.1 & 12.6 & 377122 & 8.3 \\
\hline $\begin{array}{l}\text { - work organization and } \\
\text { staff motivation }\end{array}$ & Supportive & $\mathrm{F} 2.2$ & 7.4 & 150867 & 3.3 \\
\hline $\begin{array}{l}\text { Machines and mechanisms } \\
\text { support }\end{array}$ & Basic & F3 & 20 & 1038777 & 22.9 \\
\hline $\begin{array}{l}\text { - maintenance of } \\
\text { machinery and equipment }\end{array}$ & Supportive & F3.1 & 7.4 & 425333 & 9.4 \\
\hline $\begin{array}{l}\text { - repair of construction } \\
\text { machinery and equipment }\end{array}$ & Supportive & F3.2 & 12.6 & 613444 & 13.5 \\
\hline Administrative support & Basic & F4 & 20 & 1477196 & 32.6 \\
\hline $\begin{array}{l}\text { - IT - technical support and } \\
\text { internet connection }\end{array}$ & Supportive & F4.1 & 2 & 156221 & 3.4 \\
\hline - legal support & Supportive & F4.2 & 4 & 325432 & 7.2 \\
\hline $\begin{array}{l}\text { - occupational Safety and } \\
\text { Health }\end{array}$ & Supportive & F4.3 & 2 & 65789 & 1.5 \\
\hline $\begin{array}{l}\text { - estimate and contractual } \\
\text { support }\end{array}$ & Supportive & F4.4 & 4 & 389432 & 8.6 \\
\hline $\begin{array}{l}\text { - accounting and } \\
\text { management accounting }\end{array}$ & Supportive & F4.5 & 4 & 312887 & 6.9 \\
\hline - document flow & Supportive & F4.6 & 2 & 125443 & 2.8 \\
\hline $\begin{array}{l}\text { - operation of buildings, } \\
\text { premises, territory }\end{array}$ & Supportive & F4.7 & 2 & 101992 & 2.2 \\
\hline $\begin{array}{l}\text { Construction process } \\
\text { management }\end{array}$ & Basic & F5 & 20 & 888645 & 19.6 \\
\hline $\begin{array}{l}\text { - supervision of every stage } \\
\text { of construction }\end{array}$ & Supportive & F5.1 & 8 & 478547 & 10.5 \\
\hline - works quality control & Supportive & F5.2 & 6 & 120443 & 2.7 \\
\hline $\begin{array}{l}\text { - putting the property into } \\
\text { operation }\end{array}$ & Supportive & F5.3 & 6 & 289655 & 6.4 \\
\hline
\end{tabular}

Source:calculated by the authors 
The functional cost diagram is shown in Fig. 2.

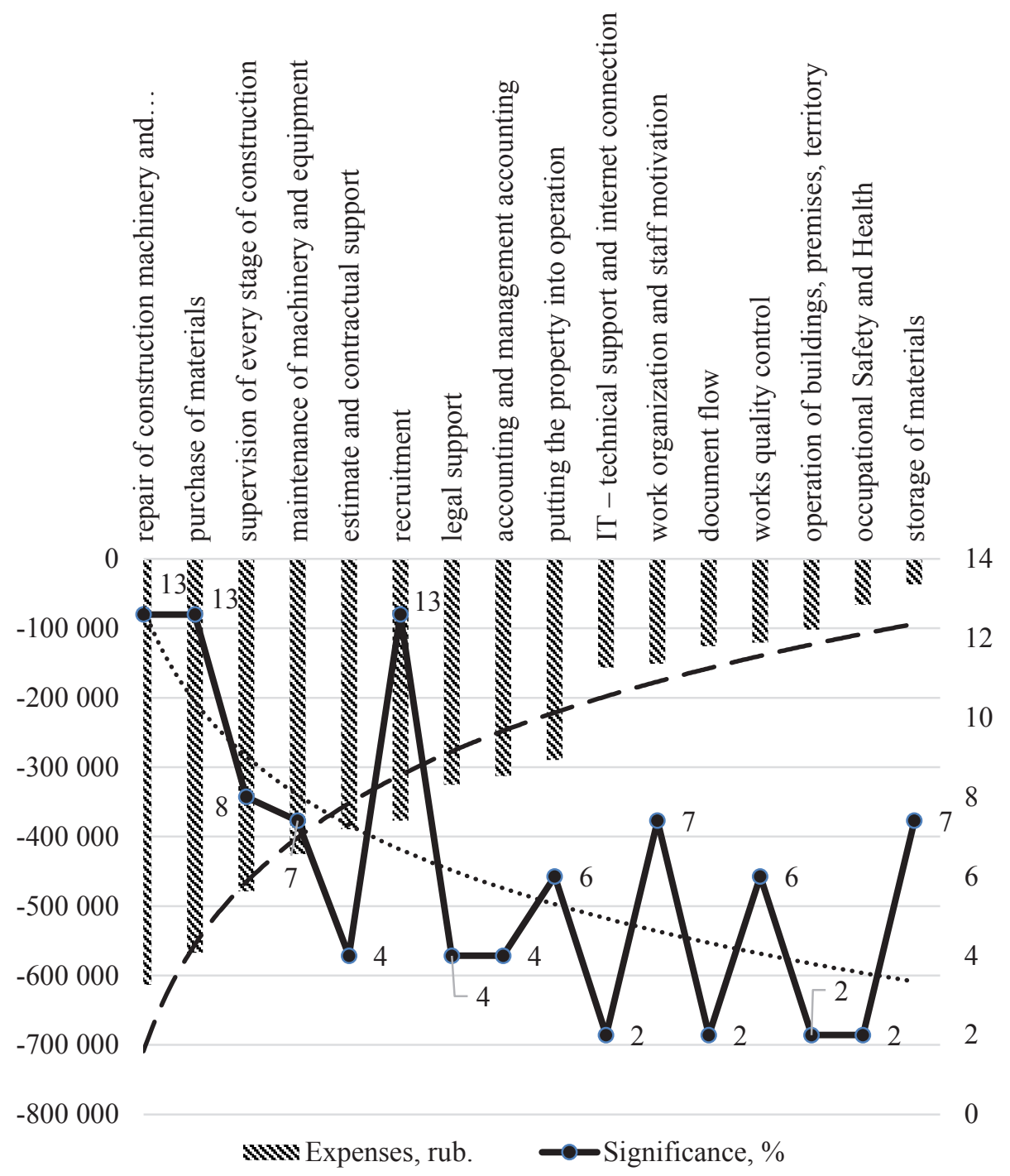

Fig. 2. Functional cost diagram. Source: calculated by the authors.

The results obtained in terms of the significance of the basic processes and their share in the structure of the main process showed that administrative support is $32.6 \%$, which is significantly higher than for other basic processes. Construction process management and machines and mechanisms support have a good ratio of significance and share of costs, and the processes of building materials and personnel supply, on the contrary, are mismatched downward. Based on the functional-cost diagram, it can be concludedthat it is these processes that become the target of analysis.

Taking functional-cost diagram as a basis, construction companies CEOs can revise the organizational structure and adjust the composition of indirect costs. 


\section{Conclusion}

Cost management problems are relevant for companies in various fields of activity. Construction is one of the leading sectors of the national economy. The main feature of the construction industry is the variety of organizational and economic forms of the construction production process. One of the factors for the effective functioning and development of a construction company is the optimal regulation of costs and their minimization.

The main part of the costs of a construction company comes from production costs. Modern experience in construction production shows an increase in the share of indirect costs in the cost of construction products.

The issue of cost management in a construction company is solved on the basis of functional and cost analysis application as an integrated approach to solving the problem of saving resources, improving the quality and competitiveness of construction products. Experts from different countries contributed to the development of the method of functional cost analysis.

The application of functional cost analysis by construction companies gives the following advantages: CEOs have reliable and accurate information about the significance of processes and the cost of work performed. It gives opportunity to make the right strategic decisions on the following aspects: improvement of the efficiency of expensive management functions; an effective combination of types of work; determination of construction products price and funds investment.

\section{References}

1. G. H. R. Braga, R. G. Cervi, P. A. de Oliveira, S. A. Rodrigues, Custos e Agronegocio, 16, $382(2020)$

2. V. K. Sinha, B. Chandra, J. K. Pattanayak, J. Mines, Met. Fuels, 68, 120 (2020)

3. A. Sušková J. Buchtová, in Met. 2020 - 29th Int. Conf. Metall. Mater. Conf. Proc., 1351-1356 (2020)

4. I. Demina, E. Bergal, D. Bezrukov, in ACM Int. Conf. Proceeding Ser. (2019)

5. W. Vetchagool, M. M. Augustyn, M. Tayles, Asian Rev. Account., 28, 329 (2020) DOI: 10.1108/ARA-08-2018-0159

6. K. Janovská, Š. Vilamová, M. Piecha, J. Kutáč, R. Kozel, J. Čitbajová, in E3S Web Conf. (2019)

7. T. Q. Vu, C. P. Pham, T. A. Nguyen, P. T. Nguyen, P. T. Phan, Q. Le Hoang Thuy To Nguyen, J. Asian Financ. Econ. Bus., 7, 389 (2020)

8. M. Tomczak P. Jaśkowski, Sustain., 13, 1 (2021)

9. I. Kharisov, I. Artamonova, P. Bilenko, S. Sborshikov, in E3S Web Conf., (2020)

10. M. K. Saidova, S. I. Xodjimuxamedova, M. A. Dadarbaev, in IOP Conf. Ser. Mater. Sci. Eng., 919, 042001 (2020) DOI:10.1088/1757-899X/919/4/042001

11. A. V. Nalimova, in IOP Conf. Ser. Mater. Sci. Eng., 913, 042027 (2020) DOI: 10.1088/1757-899X/913/4/042027

12. N. V. Chepachenko, A. A. Leontiev, G. A. Uraev, N. A. Polovnikova, in IOP Conf. Ser. Mater. Sci. Eng., 913, 042075 (2020) DOI: 10.1088/1757-899X/913/4/042075

13. K. H. Hyari, A. Al-Daraiseh, M. El-Mashaleh, J. Manag. Eng. 32, 04015021 (2016)

14. B. García de Soto, I. Agustí-Juan, J. Hunhevicz, S. Joss, K. Graser, G. Habert, B. T. Adey, Autom. Constr., 92, 297 (2018)

15. M. Habibi, S. Kermanshachi, E. Safapour, in Constr. Res. Congr., 378-388 (2018)

16. R. D. A. L.A. Koklyugina, A.V. Koklyugin, Izv. KGASU, 57 (2020)

17. O. Sklyarova, Financ. Res., 4, 210 (2019) 
18. H. Anysz, A. Nicał, Ž. Stević, M. Grzegorzewski, K. Sikora, Symmetry (Basel)., 13, 1 (2021)

19. J. Ramík, in Lect. Notes Econ. Math. Syst., 17-65 (2020)

20. N. O., Civ. Eng. Her., 293 (2015)

21. K. L, Akhmedova; N, Dagestan State Univ. Bull., 87 (2012)

22. C. E, Bull. Brest State Tech. Univ., 61 (2016)

23. J. F, Univ. Bull., 180 (2015)

24. A. N. Tarasova E. P. Karlina, Vestn. Astrakhan State Tech. Univ. Ser. Econ., 36 (2018)

25. R. A. Burganov O. A. Kolobynina, Econ. Anal. Theory Pract., 17, 1227 (2018) 